\title{
COMMENT
}

\section{THE ROLE OF THE REGISTER OF COPYRIGHTS IN THE REGISTRATION PROCESS: A CRITICAL APPRAISAL OF CERTAIN EXCLUSIONARY REGULATIONS *}

Under the Copyright Act, ${ }^{1}$ the only action required in order to obtain a valid statutory copyright in a published work is publication with the prescribed notice. ${ }^{2}$ In order to perfect the rights accruing under his copyright, however, the claimant must also "promptly" deposit two copies of the best edition of the copyrighted work, together with a claim of copyright, in the Copyright Office. ${ }^{3}$ Fulfillment of this requirement of registration and deposit is a condition precedent to any action for copyright infringement, but the copyright itself ordinarily remains valid pending fulfillment. ${ }^{4}$ Thus, although most claimants register their works as a matter of course, registration may be deferred, without loss of any rights, until the eve of suit.

Unfortunately for some copyright claimants, however, the requirement of registration cannot be satisfied by the claimant's acts alone: recent cases also require that the Register of Copyrights actually issue a certificate of registration before infringement proceedings can be brought. ${ }^{5}$ To the extent that the Register has any discretion to tition.

* This Comment has been entered in the 1968 Nathan Burkan Memorial Compe-

117 U.S.C. $\S \S 1-215$ (1964).

2 Washingtonian Publishing Co. v. Pearson, 306 U.S. 30 (1939); United States v. Backer, 134 F.2d 533 (2d Cir. 1943). 17 U.S.C. $\$ 10$ (1964), provides:

Any person entitled thereto by this title may secure copyright for his work by publication thereof with the notice of copyright required by this title; and such notice shall be affixed to each copy thereof published or offered for sale

in the United States by authority of the copyright proprietor, except in the case of books seeking ad interim protection under section 22 of this title.

17 U.S.C. $\$ 9$ (1964) defines a "person entitled" as "[ $t]$ he author or proprietor of any work made the subject of copyright by this title, or his executors, administrators, or assigns . . . " (subject to certain conditions set forth therein).

Statutory copyright is not available in unpublished works, except in certain classes of works not reproduced for sale, as to which copyright is obtained by depositing with the Copyright Office one copy of the work (or other identifying reproduction as specified by the statute), together with a claim of copyright. 17 U.S.C. $\S 12$ (1964).

317 U.S.C. $\$ 13$ (1964). In certain specified cases a single copy or other identifying reproduction will suffice.

4 Id.

5 Vacheron \& Constantin-Le Coultre Watches, Inc. v. Benrus Watch Co., 260 F.2d 637 (2d Cir. 1958) ; G. P. Putnam's Sons v. Lancer Books, Inc., 251 F. Supp. 210 (S.D.N.Y. 1966). 
determine the validity of copyright claims and to withhold the certificate if he decides a claim is invalid, he can vitally affect a claimant's right to enforce his copyright. It is the purpose of this Comment to focus attention on the extent of the Register's discretion to refuse registration, examining the theoretical and legal bases for its existence, how it has in fact been exercised through Copyright Office regulations, and what remedies should be made available to those who may be adversely affected by the Register's decision.

\section{Registration}

Unlike the Commissioner of Patents, whose statutory function is to grant or deny applications for patents after conducting a thorough search of his files and examining the inventions submitted to ascertain whether or not they meet certain statutory standards, ${ }^{6}$ the Register of Copyrights is not charged with the function of granting copyright protection. With respect to copyright in published works, section 10 of the Copyright Act provides:

Any person entitled thereto by this title may secure copyright for his work by publication thereof with the notice of copyright required by this title.... ${ }^{7}$

With respect to certain classes of works not reproduced for sale, section 12 provides that copyright "may . . . be had" by making the appropriate deposit, accompanied by claim of copyright. ${ }^{8}$ Thus, the steps required to secure copyright lie wholly within the control of the copyright claimant.

Notwithstanding the fact that copyright inheres in a work before the Register has taken any action, registration is not optional. Section 13 requires registration of all claims to copyright, together with prompt deposit of copies of all works, published and unpublished, in which copyright is claimed. ${ }^{9}$ This requirement of deposit and registration is of vital importance to the functioning of the copyright system. Were it not for the central depository and file provided by the Copyright Office, it might be an exceedingly difficult task for a person desiring to make legal copies of copyrighted matter to discover the identity and whereabouts of the copyright proprietor, espe-

B 35 U.S.C. $\$ \S 100-04,131$ (1964).

717 U.S.C. $\$ 10$ (1964). The requirements regarding the proper form and placement of the copyright notice are specified in 17 U.S.C. $\$ 19$ (1964).

817 U.S.C. $\$ 12$ (1964). Works covered by this section include lectures and similar productions; dramatic, musical and dramatico-musical compositions; motion picture photoplays; photographs; motion pictures other than photoplays; and works of art, plastic works, and drawings.

917 U.S.C. $\$ 13$ (1964). 
cially if the copyright had been assigned, ${ }^{10}$ or renewed in the name of someone other than the author. ${ }^{11}$ The records made up from registrations thus assist both proprietors and users by making public and easily accessible much valuable information which would otherwise remain unknown or difficult to locate. ${ }^{12}$

Despite the importance of registration, however, the drafters of the Copyright Act of 1909 chose not to invoke the drastic sanction of forfeiture of copyright for failure to register, as had been done in earlier acts. ${ }^{13}$ Instead, they relied chiefly ${ }^{14}$ on the expedient of making registration and deposit conditions precedent to any right of action for copyright infringement:

No action or proceeding shall be maintained for infringement of copyright in any work until the provisions of this title with respect to the deposit of copies and registration of such work shall have been complied with. ${ }^{15}$

Although the statute makes registration a prerequisite to any action for infringement, it was at first not thought necessary that the Register actually issue a certificate of registration. The statute nowhere defines compliance for the purpose of section 13, and the

10 The Copyright Act provides that "Copyright secured under this title or previous copyright laws of the United States may be assigned, granted, or mortgaged by an instrument in writing signed by the proprietor of the copyright, or may be bequeathed by will." 17 U.S.C. $\$ 28$ (1964). The Act facilitates tracing of assignments by requiring that "[e]very assignment of copyright shall be recorded in the copyright office within three months after its execution" (or six months, if executed outside the United States). If this is not done, the assignment becomes "void as against any subsequent purchaser or mortgagee for a valuable consideration, without notice, whose assignment has been duly recorded." Id. $\$ 30$. These records are an indispensable aid to one who wishes to trace title to a copyright.

11 The Copyright Act provides that a copyright, once secured, shall run for a term of 28 years from the date of first publication of the work (17 U.S.C. $\$ 24$ (1964)), or from the date of prior deposit (if any) as an unpublished work. Marx v. United States, 96 F.2d 204 (9th Cir. 1938) ; see Rose v. Bourne, Inc., 176 F. Supp. 605, 608 (S.D.N.Y. 1959), aff'd, 279 F.2d 79 (2d Cir. 1960). The initial term of copyright may be extended for a renewal period of 28 years, provided a renewal copyright has been obtained in accordance with the requirements of the statute. 17 U.S.C. $\$ 24$ (1964). In most cases, the renewal may be obtained only by the original author or by one of his statutorily designated successors. Id. In certain enumerated types of works, however, the renewal copyright vests not in the author, but in the person who is the proprietor of the work at the time the renewal vests. Id. The problem of determining who is entitled to the renewal, and the manner in which it is to be obtained, has generated much litigation. See, e.g., DeSylva v. Ballentine, 351 U.S. 570 (1956); Fred Fisher Music Co. v. M. Witmark \& Sons, 318 U.S. 643 (1943). See generally M. Nimmer, Copyright $\$ \S 112-18$ (1967).

12 For an appraisal of the values of the present registration system see Kaplan, The Registration of Copyright, in 1 STUDIES on COPYRIGHT 325, 366-71 (1963).

13 See, e.g., Rev. Stat. § 4956 (1873).

14 Also available but rarely used are the sanctions provided in 17 U.S.C. $\S 14$ (1964): if the copies called for by $\S 13$ are not promptly deposited, the Register may at any time after the publication of the work, upon actual notice, require the proprietor of the copyright to deposit them. If the copies are not deposited within a specified time after the making of the demand, the proprietor of the copyright is liable for a fine of $\$ 100$ as well as twice the amount of the retail price of the best edition of the work, and the copyright becomes void.

1517 U.S.C. \& 13 (1964). 
early decisions apparently assumed that compliance only by the claimant and not by the Register was all that was required. In other words, they assumed that a claimant would be entitled to bring suit for infringement once he had mailed his copy or copies to the Register of Copyrights, accompanied by the appropriate registration forms and statutory fees. This was the reasoning in White-Smith Music Publishing Co. v. Goff, ${ }^{16}$ in which plaintiff sought to enjoin defendant from infringing its copyrighted musical composition, basing its claim to copyright on an assignment of the author's renewal rights. The Copyright Office had refused to register the claim, apparently on the ground that plaintiff was not entitled to the renewal. Nevertheless, the court noted that plaintiff had "offered registration under the statute," saying that "although registration was refused, yet [the plaintiff] fully complied with the requirements of law, and is entitled to maintain this suit if it had any statutory right to the extension." 17

The first contrary reading of the statute came in 1921, in Lumière v. Pathé Exchange, Inc. ${ }^{18}$ Lumière involved a photographer who, at the time of filing a bill for an injunction to restrain infringements of his copyright in three photographs, had made the required deposit but had not yet obtained the certificate of registration. The court held that actual possession of the certificate was a prerequisite to bringing suit and dismissed the complaint. But by far the most significant and devastating decision to copyright claimants was that of the Court of Appeals for the Second Circuit in Vacheron $\mathcal{E}$ Constantin-Le Coultre Watches, Inc. v. Benrus Watch Co. ${ }^{19}$ Plaintiff had claimed copyright as a work of art in its elaborately designed, jewel-studded watch and applied for registration (Class $G$ ). ${ }^{20}$ The Register declined to issue a certificate of registration on the ground that the watch was not a work of art, but an article whose sole intrinsic function was its utility. ${ }^{21}$ The district court agreed with the Register that the watch was uncopyrightable and dismissed the complaint on the copyright count. ${ }^{22}$ Judge Learned Hand, writing for the majority

16187 F. 247 (1st Cir. 1911). See also New York Times Co. v. Star Co., 195 F. 110,112 (S.D.N.Y. 1912) (dictum).

$17187 \mathrm{~F}$. at 247.

18275 F. 428 (2d Cir. 1921), followed in Rosedale v. News Syndicate Co., 39 F. Supp. 357 (S.D.N.Y. 1941).

19260 F.2d 637 (2d Cir. 1958), affir'g in part on other grounds and rev'g in part 155 F. Supp. 932 (S.D.N.Y. 1957).

2017 U.S.C. $\$ 5(\mathrm{~g})(1964)$.

21 See 155 F. Supp. at 934. The Register probably based his determination on $\$ 202.10$ (c) of the Copyright Regulations, 37 C.F.R. $\$ 202.10$ (c) (Supp. 1956): "If the sole intrinsic function of an article is its utility, the fact that it is unique and attractively shaped will not qualify it as a work of art. However, where the object is clearly a work of art in itself, the fact it is also a useful article will not preclude registration." Compare the current version of this regulation, quoted and discussed in text at note 135 infra.

22 The court also dismissed a count based on a charge of unfair competition but granted plaintiff a permanent injunction against infringement of a design patent which it had obtained upon the watch. $155 \mathrm{~F}$. Supp. at 937. 
of the Court of Appeals, assumed that the watch was copyrightable but affirmed the lower court's disposition of the copyright count on the ground that no action for infringement could be brought until the work had actually been registered and a certificate of registration issued. $^{23} \mathrm{He}$ characterized the contrary position espoused in the White-Smith case ${ }^{24}$ as dictum, resting the immediate decision chiefly on his reading of the statute. ${ }^{25}$

Under this holding, the only recourse open to a copyright claimant denied registration who desires to sue for infringement is to bring a separate action for mandamus to compel the issuance of a certificate. ${ }^{26}$ The requirement imposed by Vacheron on the unsuccessful applicant for copyright registration is formidable. Not only must he undergo the expense of two successive actions in order to vindicate his claim, but he must also risk the possibility that, if the infringement is a continuing one, his injury will be aggravated while he proceeds against the Register. The extra time involved in bringing the latter action might even cause the staute of limitations to run on his infringement action. ${ }^{27}$

These burdens are sufficiently serious to have caused the Register himself to characterize the plight of the unsuccessful registrant as "unfortunate" and to advocate legislative overruling of the Vacheron case in the Copyright Revision Bill. ${ }^{28}$ However, even if Lumière and Vacheron had not established the necessity of obtaining a certificate of registration (as opposed to merely applying for one) before bringing an infringement action, the Register's initial refusal to register could adversely affect the claimant in several ways. For instance, section 209 of the Copyright Act provides that the certificate, when completed, "shall be admitted in any court as prima facie evidence of the facts stated therein." 29 Assuming for the purposes of discussion that the rule of the White-Smith case were still good law and that an infringement action could be brought despite the Register's refusal to issue a certificate, such refusal would nevertheless deprive the claimant of the procedural advantage of this presumption. This advantage is not inconsiderable, for the facts stated in the certificate will, if not controverted, supply the basis for establishing the subject matter, ownership

23260 F.2d at 639 . The court reversed and remanded the judgment granting a permanent injunction upon the design patent count for a trial on the issue of originality. Id. at 641-42.

24 See text accompanying notes 16-17 supra.

25 See 260 F.2d at 640-41. But see dissenting opinion of Clark, J., id. at 645-46.

$26 I d$. at $640-41$ (by implication). The court refused to continue the action pending the outcome of such a mandamus action.

27 See the suggestion of Clark, J., in his dissenting opinion in id. at 645. Any civil action under title 17 must be commenced no more than 3 years after the claim accrued. 17 U.S.C. $\$ 115$ (b) (1964).

28 House Comm. on the Judictary, 87Th Cong., 1st Sess., Report of the Register of Copyrights on the General Revision of the U.S. Copyright Law 75 (Comm. Print 1961).

2917 U.S.C. $\$ 209$ (1964). 
and existence of the copyright. ${ }^{30}$ Without the benefit of the presumption, the claimant would have to prove each of these items separately. Even more significant than the procedural advantage expressly granted by the statute, however, is the widely-held judicial view that the certificate of registration raises a prima facie presumption of the validity of the copyright, ${ }^{31}$ and the likelihood that courts would apply the converse of this view to create a reverse presumption of invalidity in the event that the Register had refused to issue a certificate. ${ }^{32}$

30 Specifically, $\$ 209$ requires the certificate of registration to contain the name and address of the claimant, the country of the author's citizenship, his name (when shown by the Copyright Office records), the title of the work, the date of deposit of copies, the date of publication (if any), the class designation and entry number, and (in the case of a book) the statement of receipt of affidavit of manufacture and date of completion of printing or publication date as stated in the affidavit.

31 Courts generally give effect to the language of 17 U.S.C. $\$ 209$ (1964) by holding that prima facie effect must be given to the statements in the certificate, whether or not within the Register's "personal knowledge." See, e.g., Jerry Vogel Music Co. v. Forster Music Publisher, Inc., 147 F.2d 614 (2d Cir. 1945). In some cases, however, courts have gone even farther and have spoken broadly of the certificate as presumptive evidence of the validity of the copyright, or of the plaintiff's title. See, e.g., Wihtol v. Wells, 231 F.2d 550, 553 (7th Cir. 1956) ; Magnus Organ Corp. v. Magnus, 269 F. Supp. 981, 984 (D.N.J. 1967) ; Freudenthal v. Hebrew Publishing Co., 44 F. Supp. 754, 755 (S.D.N.Y. 1942).

32 The probability that a court will defer to the Register's decision that a given work is uncopyrightable and therefore ineligible for registration is directly related to the court's view of the extent of discretion accorded by the Copyright Act to him in deciding this kind of question. The greater the Register's scope of discretion, the less willing the court may be to disturb his decision.

There is considerable evidence pointing to the existence of only a limited degree of discretion on the part of the Register. No case has been found in which a court rested its affirmance of the Register's denial of a certificate on judicial deference to his decision; on the contrary, in all the mandamus actions brought against him in which his decision was affirmed, the court has agreed with him on the merits of the case.

There are but two cases in which the Register's refusal of registration was later overturned by a court: United States ex rel. Twentieth Century-Fox Film Corp. v. Bouvé, 33 F. Supp. 463 (D.D.C. 1940), aff'd, 122 F.2d 51 (D.C. Cir. 1941), and King Features Syndicate, Inc. v. Bouvé, 48 U.S.P.Q. 237 (D.D.C. 1940). Since the two - cases are similar in all essential respects, only the first, whose opinion more completely discusses the issues, will be examined. In that case, plaintiff had sought registration of a book, in Class A, 17 U.S.C. \$ 5(a) (1964), for page proofs of contributions to periodicals bound together in book form, and had tendered a single registration fee. The Register denied the application on the ground that the submitted material was not a book but rather separate page proofs of 20 contributions to periodicals, and that a separate registration and fee was required for each one. (In so deciding, he relied, inter alia, on the following language in 17 U.S.C. $\$ 13$ (1964): "After copyright has been secured by publication of the work with the notice of copyright as provided in section 10 of this title, there shall be promptly deposited in the Copyright Office or in the mail addressed to the Register of Copyrights, . . . two complete copies of the best edition thereof then published, . . . or if such work be a contribution to a periodical, for which contribution special registration is requested, one copy of the issue or issues containing such contribution ....") Plaintiff then petitioned for a writ of mandamus against the Register to compel him to accept the application for registration as a book, which writ was granted by the district court. $33 \mathrm{~F}$. Supp. 463 (D.D.C. 1940).

In affirming the grant of mandamus, the court of appeals said of the Register that "[i]t does not follow that he has power to exercise uncontrolled discretion in refusing registration of material which is subject to copyright, merely because he disagrees with the author as to how it should be classified." 122 F.2d at 54 . It also held that "assuming that he has full power to classify deposited material, still, this gives him no power to refuse registration of a claim to copyright, which has been already secured by publication and notice; if the claim is based upon material which is 
Finally, denial of the certificate will necessarily deprive the applicant of the various advantages of registration apart from those relating to infringement actions, ${ }^{33}$ perhaps the foremost among these being the readiness with which a certificate is accepted as evidence of copyright ownership for the purposes of transfer of title. ${ }^{34}$

From a first reading of the statute, the procedure for obtaining a certificate of registration appears virtually automatic; that is, the Register is given no express discretion to decline to issue a certificate of registration. Section 11 provides:

actually the subject of copyright." $I d$. at 54-55. The court held that it had power to review the Register's determination, and found it clearly erroneous as a matter of law.

Despite limits on the Register's discretion when it comes to denying registration of material that is "actually the subject of copyright," however, and apart from the standard of review that may be applied (see id. at 54), the court also made it clear that it did regard the statute as giving the Register some discretion to refuse registration. It rested this determination partly on its construction of the statute, now 17 U.S.C. $\$ 207$ (1964), which provides: "Subject to the approval of the Librarian of Congress, the Register of Copyrights shall be authorized to make rules and regulations for the registration of claims to copyright as provided by this title." The court reasoned that this language "must contemplate the exercise of some discretion, not only in the making, but in the administration of such rules." 122 F.2d at 53 . Another reason for holding the Register empowered to refuse applications could be found in practical considerations :

In light of recent trends and the divergent philosophies of different schools of thought as to what constitutes art, to say nothing of the large possibilities inherent in plastic works of a scientific or technical character, it seems obvious that, unless the Register has some power to control deposits for copyright, it may soon become necessary to build a new library annex. It seems obvious, also, that the Act establishes a wide range of selection within which discretion must be exercised by the Register in determining what he has no power to accept.

Id. (Emphasis in original). Finally, the court found there was no doubt "that the Register may refuse to issue a certificate of registration until the required fee is paid, and until other formal requisites of the Act have been satisfied." Id. at 53-54.

In other words, although the functions of the Register in regard to registration of claims may be regarded as ministerial inasmuch as he has a duty to register claims which are submitted in accord with the statutory requirements and whose subject matter is clearly copyrightable, it is nevertheless clear that he does have "discretion" to the extent that copyrightability is doubtful, that is, to the extent that he must exercise judgment in construing the statute and in applying it to determine the eligibility of a particular claim. See Berger, Authority of the Register of Copyrights to Reject Applications for Registration, in 1 STUDIEs ON COPYRIGHT 404 (1963).

Given that the Register's discretion is limited, it is clear that some discretion does exist, especially in ascertaining whether a submitted work constitutes copyrightable subject matter under the statute. While any exercise of this discretion will be reviewable, there is clearly a danger, from the applicant's point of view, that the reviewing court will defer to the Register's decision unless it is found to be patently erroneous. This danger exists all the more because no statutory provision for judicial review of the Register's decisions has been made. The applicant must therefore resort to the extraordinary writ of mandamus as a substitute for review; but he will probably find that mandamus can give him only limited relief. See the discussion of the limitations of mandamus at notes 166-68 infra and accompanying text.

33 See text at note 12 sipra.

34 For a list of the advantages of registration to copyright proprietors and others, see Kaplan, supra note 12, at 368-69. Among the other advantages of registration to the author of copyright proprietor is that Copyright Office records aid in protecting registered works against unauthorized use by informing would-be users of the material of the copyright's existence and of the name of the copyright proprietor where these facts are not evident from the notice itself, as where the copyright has been assigned or renewed in the name of someone other than the author. 
Such person may obtain registration of his claim to copyright by complying with the provisions of this title, including the deposit of copies, and upon such compliance the Register of Copyrights shall issue to him the certificates provided for in section 209 of this title. ${ }^{35}$

Some have concluded from this that the Register's function is wholly ministerial, involving no power to decline to issue a certificate, at least so long as there has been compliance with the formal requisites of the statute. ${ }^{36}$ Other parts of the statute, however, indicate that the drafters must have intended to give the Register, at minimum, sufficient discretion to turn down claims he finds to be wholly without merit. ${ }^{37}$ Reference has already been made to the prima-facie presumption of validity accorded by section 209 to the facts stated in the certificate. ${ }^{38}$ It has been argued with good reason that this provision would be rendered meaningless if the Register were bound to issue a certificate automatically to every claimant upon receipt of the claim and accompanying deposit. If such were the case, the certificate could hardly be of greater evidentiary weight than the unsupported assertions of the copyright claimant; it is therefore difficult to see on what basis the presumption of validity might be justified. ${ }^{39}$ Also, section 207 gives the Register authority to make "rules and regulations for the registration of claims to copyright as provided by this title." 40 If these provisions are to be given any effect, it seems clear that the

3517 U.S.C. $\$ 11$ (1964) (emphasis added).

36 See authorities cited by Kaplan, supra note 12, at 367 .

${ }^{37}$ In Bouvé v. Twentieth Century-Fox Film Corp., 122 F.2d 51, 53 (D.C. Cir. 1941), the court stated:

[T] he Register may properly refuse to accept for deposit and registration "objects not entitled to protection under the law." . . . It seems obvious, also, that the Act establishes a wide range of selection within which discretion must be exercised by the Register in determining what he has no power to accept.

See also Bailie v. Fisher, 258 F.2d 425 (D.C. Cir. 1958).

3817 U.S.C. $\$ 209$ (1964). See text accompanying note 29 supra. The facts required to be contained in the certificate are enumerated in note 30 sipra.

39 See 30 Or. ATT'X GEN. 422, 424-25 (1915):

The suggestion that the determination of the validity of the registration should be left to the courts, and the necessary inference involved that the duty of the register is purely automatic, and consists wholly (with the single exception of books) in determining whether the subject presented is ... within the general class of articles which may be copyrighted, can not be reconciled with the power vested in the register to issue rules and regulations under which he will permit registration under the law. That section of the law plainly indicates that he has at least some measure of discretion in the administration of the act. Manifestly, in the exercise of that discretion he may make such investigation and require such showing of compliance with the law as may be necessary to enable him to determine whether the prerequisites imposed have been met.

Cf. Bouvé v. Twentieth Century-Fox Film Corp., 122 F.2d 51, $52-54$ (D.C. Cir. 1941) ; 41 Or. ATr'y GEN. 395, 396-98 (1958). See also Fisher, The Copyright Office and the Examination of Clains to Copyright, in 1953 Copyriget Problens ANALYzed 11, 15-17 (T. Kupferman ed. 1953).

4017 U.S.C. $\$ 207$ (1964). 
Register must have at least the power to refuse registration to a work if the applicant is not a person entitled to copyright protection, or if the claim falls wholly outside the scope of copyrightable subject matter or fails on its face to comply with one or more of the statutory requisites of copyright protection, such as proper placement of notice. ${ }^{41}$

Several cases have upheld the Register's action in declining to make registration and to issue a certificate in specific instances, thereby giving weight to the view that he has the power to do so. ${ }^{42}$ The United States Attorney General has added the weight of his authority to this view of the statute in an official opinion. ${ }^{43}$ But owing to the indefiniteness of the statute and the dearth of case law on the point, the outer limits of the Register's discretion have never been defined.

Perhaps the principal reason that the point has not been extensively litigated is that the Register has shown relatively little inclination to probe the limits of his discretion. ${ }^{44}$ Notwithstanding his powers, he would no doubt acknowledge that his office is ill-equipped and ill-suited to undertake a complete assessment of the validity of each copyright claim received: there are too many factors affecting copyrightability whose impact cannot be ascertained simply by examining the deposited work or the accompanying application. ${ }^{45}$ For example,

41 [I]f the Copyright Office were to register claims and issue certificates without regard to the copyrightability of the material, the result would be to mislead the applicant and the public. What materials are copyrightable is a rather esoteric question on which the general public is not well informed. Many applications are received in the Copyright Office for the registration of uncopyrightable material such as titles, names, ideas, mechanical devices, tools, toys, and almost anything imaginable, usually under a misapprehension by the applicant of the copyright law. In some instances, protection may be available under the trademark or patent laws. Registration of a copyright claim in such material would lull the applicant into a false sense of security in believing he had copyright protection, instead of seeking advice and other means of protecting his interests; and the public would often be given the false impression that the material is copyrighted. Further consequences would also seem evident: the registration records would be cluttered with unfounded claims; registration records and certificates would be unreliable and would lose much of their probative value for copyright claimants, for other persons dealing with them, and for the courts; and many unfounded claims would probably become the source of litigation.

Berger, Authority of the Register of Copyrights to Reject Applications for Registration, in 1 Studies on Copyright 393, 405 (1963).

42 Bailie v. Fisher, 258 F.2d 425 (D.C. Cir. 1958) ; Brown Instrument Co. v. Warner, 161 F.2d 910 (D. C. Cir. 1947) , Vacheron \& Constantin-Le Coultre Watches, Inc. v. Benrus Watch Co., 155 F. Supp. 932 (S.D.N.Y. 1957), aff'd in part and rev'd in part, on other grounds, 260 F.2d 637 (2d Cir. 1958).

4330 Op. ATr'y GEN. 422 (1915). This view was confirmed in a more recent opinion dealing specifically with the Register's power to decline registration of a work on the ground that it is obscene or otherwise illegal, 41 OP. ATr'y GeN. 395 (1958).

44 It is the announced policy of the Copyright Office to make registration of claims in doubtful cases. This policy is discussed more fully in the text accompanying note 48 infra.

45 In addition to the impossibility of assessing all the factors which enter into a determination of copyrightability on the sole basis of an applicant's submissions, a former Register of Copyrights has pointed out that there is a severe restriction on the amount of time that can be devoted to any given application. Of the more than 1,000 applications for registration received every day (each primary examiner must process about forty of these to keep the workload current), approximately 850 , or $85 \%$, ap- 
since the Copyright Office makes no attempt to conduct a search of its files before making registration, there is no way in which it is possible to determine by inspection whether or not a given work constitutes an original work of authorship, except in the rare instance when the examiner might recognize a plagiarism of a work with which he was already familiar. ${ }^{46}$ About the most that can ordinarily be done is to ascertain whether the work fits under one of the statutory classifications of copyrightable subject matter; whether the required notice is adequate; whether there is agreement in dates, names, etc., between the application and the deposited copies; and possibly to determine some other matters, such as whether the author is a person entitled to copyright. ${ }^{47}$ Even within the narrow confines to which practical limitations restrict the Register's range of inquiry, however, close questions calling for nice judgments can arise. This is especially true in the area of copyrightable subject matter, as will be seen below.

\section{Copyright Office Registration Practice as Codified in Exclusionary Regulations}

\section{A. The Register's Own Conception of His Role: The "Rule of Doubt"}

Realizing the consequences that refusal to issue a certificate can entail and knowing that the Copyright Office has not been endowed with the primary function of adjudicating the validity of copyright claims submitted to it, the Register has traditionally followed a policy of making registration in doubtful cases. Known variously as the "rule of doubt" or the "rule of doubtful validity," this policy has been stated as follows:

Instead of requiring an applicant to prove his case, the examiners are prepared to prove a case for rejecting before they make such a recommendation. We will register material which we feel a court might reasonably hold to be copyrightable, even though, personally, we feel that it is not subject to copyright. 48

pear to be in proper form and to meet all the statutory requirements. A brief examination of the remaining $15 \%$ reveals that they depart in some way from the statutory formalities. Fisher, sippra note 39 , at 15 . See also Kaplan, supra note 12, at 361-62. More recent figures indicate that the number of applications has increased. In fiscal 1966, for example, 286,866 registrations were made in all categories (no figures were published regarding the total number of applications received). 69 Register of COPYRIghts ANN. RER. 33 (1967). Unofficial figures for 1967 disclose that 323,415 applications were received, resulting in approximately 294,000 registrations. Interview with Richard E. Glasgow, Esq., Chief of Examining Division, United States Copyright Office, in Washington, D.C., Jan. 15, 1968. Assuming a working year of 250 days, this means that in 1967 the Copyright Office processed an average of nearly 1300 applications per day.

${ }_{40}$ See Berger, supra note 41 , at 403 n.38.

47 See Kaplan, supra note 12, at 361-62.

48 Library of Congress, Department \& Divisional Manuals, No. 7, "Copyright Office" 38 (1950). See also Fisher, supra note 39 , at 16. 
Under this policy it would seem that the Register should refuse to issue a certificate only in the event that the claim submitted has virtually no chance of withstanding an eventual challenge in the courts. In practice, however, certain categories of would-be registrants find it more difficult to obtain a certificate than the above statement implies.

\section{B. The Mechanics of Processing Copyright Claims and the Need for Standards of Exclusion ${ }^{49}$}

Upon receipt of an application for registration, the application form and accompanying deposit are sent to an examiner whose function is to ascertain whether or not a certificate should issue. If the submitted material is clearly copyrightable and if there has been compliance with the other statutory requisites, the certificate will normally be issued as a matter of course. Should a question arise, the examiner will write to the applicant and attempt to secure whatever further information or clarification is needed. If, after examining the deposit and all the pertinent information regarding it, the examiner decides that the material is not copyrightable or that the applicant is not entitled to copyright, the applicant will be notified of the rejection and of the reasons therefor. The applicant may then request reconsideration, in which case the initial decision is reviewed de novo by the head examiner of the appropriate section of the Examining Division, ${ }^{50}$ who takes into account whatever arguments the applicant advances in favor of acceptance. If the decision is confirmed, further appeals lie to the Assistant Chief and, ultimately, to the Chief of the Examining Division. In rare cases presenting questions of particular importance it may be possible to appeal to the Register, but ordinarily, if the Chief of the Examining Division affirms the initial examiner's denial, the applicant's only recourse lies in bringing an action of mandamus against the Register. As mentioned above, the statute makes no provision for further administrative review or for direct review of such denials by a court. In fact, even the informal procedure just described is not required by statute; it has evolved solely on the initiative of the Register in the interest of fairness to copyright applicants.

Given the lack of statutory guideposts for the exercise of his discretion in passing upon applications for registration, yet faced with the necessity of establishing minimal administrative standards of exclusion which will enable his staff to process the flood of applications

49 The following explanation is based on the writer's interview with Messrs. Richard E. Glasgow and Arthur J. Levine, respectively Chief and Assistant Chief of the Examining Division, United States Copyright Office, in Washington, D.C., January 15,1968 . For a brief summary of the procedure followed in the Examining Division, see Kaplan, sipra note 12 , at $361-62$.

50 In order to facilitate the process of examination, the Examining Division is subdivided into four sections entitled "Arts," "Music," "Books," and "Renewals and Assignments," respectively. Each of these sections is supervised by a head examiner. 
with reasonable dispatch, ${ }^{51}$ the Register has had to formulate various policy statements defining specific categories of material that he regards as clearly ineligible for copyright under the statute and its judicial interpretations. While some of the statements are intended only for the internal use of the Copyright Office and hence are not generally available, the Register has traditionally published other regulations dealing with registration of claims to copyright for the guidance of the public. ${ }^{22}$ Some of these deal with purely administrative and procedural matters, such as the proper procedure to be followed in submitting applications for copyright ${ }^{53}$ or the conditions under which photographs of the copyrighted work may be deposited in lieu of copies required by section $13 .^{54}$ Most of the published regulations, however, attempt to define the scope of the statutory classifications of copyrightable subject matter.

In addition to providing general definitions, many of the regulations offer specific examples of the types of works which will or will not be accepted for registration..$^{55}$ Some of the regulations in this latter category are designed to forestall certain obvious misunderstandings as to the scope of copyrightable subject matter. For example, under Class I (drawings or plastic works of a scientific or technical nature), a regulation makes it clear that the term "plastic work" refers to a three-dimensional work giving the effect of that which is molded or sculpted, and not to every object made of one of the synthetic chemical derivatives, plastics. ${ }^{56}$

\section{Regulations That Define the Register's Discretion Too Broadly or Too Narrowly}

Unfortunately, not all the questions that the regulations undertake to resolve are inherently capable of such clear-cut answers, and not all the regulations are so easily justified. In certain cases, disputed questions of copyrightability have been arbitrarily settled by regulations that leave insufficient scope for the application of the rule of doubt. In others, the arbitrariness lies not in the regulations themselves, but in the nature of the judgment that they require the Register to exercise. Careful consideration of these regulations is necessary in order to understand fully the problems they create and the reforms in the law that these problems suggest.

61 For statistics on the number of applications that must be processed daily, see note 45 supra.

62 The Register of Copyrights is authorized to make rules and regulations for the registration of claims to copyright by 17 U.S.C. $\$ 207$ (1964). The current regulations are codified in 37 C.F.R. ch. 2 (1967). For a compendium of past regulations, see United States Library of Congress, Copyright Office, A Compilation of the Regulations Concerning Copyright, 1874-1956 (1956) (microfilm).

5337 C.F.R. $\$ 202.3$ (1967).

54 Id. $\$ 202.16$.

55 These regulations elaborate on the classes enumerated in 17 U.S.C. $\$ 5$ (1964),

5637 C.F.R. \$202.12(b) (1967). 


\section{Regulations Categorically Excluding a Class of Works}

The Register has promulgated relatively few regulations categorically stating that broad classes of works are not copyrightable, since most determinations of copyrightability involve questions of judgment and hence must be made on a case-by-case basis. There are, however, two hard and fast rules involving the copyrightability of a work with respect to which a patent has been obtained, and both are open to challenge.

The first of these rules is found among the regulations pertaining to works of art (Class $G$ ). The regulation provides:

The potential availability of protection under the design patent law will not affect the registrability of a work of art, but a copyright claim in a patented design or in the drawings or photographs in a patent application will not be registered after the patent has been issued. ${ }^{57}$

The second rule relates to drawings or plastic works of a scientific or technical character (Class I) :

A claim to copyright in a scientific or technical drawing, otherwise registrable in Class I, will not be refused registration solely by reason of the fact that it is known to form a part of a pending patent application. Where the patent has been issued, however, the claim to copyright in the drawing will be denied copyright registration. ${ }^{58}$

The first rule forecloses the possibility of obtaining copyright registration for a patented design; the second prohibits the registration of a scientific or technical drawing which forms part of an issued patent. In both cases, the reason for the denial is obscure. Nowhere does the statute require any such result, and the possibility of dual protection has not been foreclosed by the courts.

In the field of works of art, the landmark case is Mazer $v$. Stein, ${ }^{59}$ in which the Supreme Court held that an independently copyrightable work of art is not rendered uncopyrightable by virtue of its subsequent inclusion in a useful article. It expressly declined to decide whether the allowance of either a copyright or a design patent on a given work

$57 \mathrm{Id} . \$ 202.10$ (b). One might wonder how the Copyright Office could know officially whether or not a patent had already been issued. The answer probably lies in 35 U.S.C. \&287 (1964), which provides:

Patentees, and persons making or selling any patented article for or under them, may give notice to the public that the same is patented, either by fixing thereon the word "patent" or the abbreviation "pat.", together with the number of the patent, or when, from the character of the article, this can not be done, by fixing to it, or to the package wherein one or more of them is contained, a label containing a like notice. In the event of failure so to mark, no damages shall be recovered by the patentee in any action for infringement. 5837 C.F.R. $\$ 202.12$ (c) (1967).

59347 U.S. 201 (1954). This case is analyzed in the text accompanying notes 120-23 infra. 
bars the grant of the other. ${ }^{60}$ The Court has never resolved this issue, and no lower court has squarely held that such dual protection is necessarily unobtainable. The one case cited informally ${ }^{61}$ by the Copyright Office as a basis for this regulation, Louis De Jonge \& Co. $v$. Breuker \& Kessler Co., ${ }^{62}$ affords it very little support. In De Jonge, which arose under the Copyright Act of $1874,{ }^{63}$ plaintiff brought an action for infringement of his copyrighted painting which he used as the basis of a design on gift-wrapping paper. Defendant contended that plaintiff should have obtained a design patent for his painting, and thus copyright protection had to be barred, arguing that the areas covered by the patent and copyright statutes were mutually exclusive. After deciding that the painting was within the scope of the copyright law, the court rejected the defendant's argument, saying that there was some area of overlap between copyright and patent, and that if a given work appears eligible for both forms of protection, either one could be chosen. ${ }^{64}$ The court did add its opinion that as soon as one of these monopolies was granted, the other became unavailable. ${ }^{65}$ This last statement was clearly dictum, since the plaintiff had made no application for a patent, and the only issue that had to be decided was whether the mere availability of a patent barred the validity of the copyright. This dictum may perhaps be attributable to the court's fear of unduly extending one of these two statutory monopolies by superimposing the protection of the other.

In the case of scientific or technical drawings, the regulation in question apparently stems from the decision of the Court of Appeals for the Second Circuit in Korzybski v. Underwood \& Underwood, Inc. ${ }^{66}$ in which a second theory was advanced as requiring the denial of dual patent and copyright protection to the same work. The court held that the drawings or diagrams forming part of a patented invention are dedicated to the public in what amounts to a compulsory divestive publication, and therefore may not be copyrighted.67 The court observed that the patent dedicates both the invention and the drawings, subject only to the inventor's monopoly to make, use, and vend the invention during the term of the patent.

This argument does not purport to rest on broad policy grounds, but rather on a narrow legal technicality. ${ }^{68}$ Even assuming its validity,

$60 \mathrm{Id}$. at 217.

01 Interview with Messrs. Richard E. Glasgow and Arthur J. Levine, respectively Chief and Assistant Chief of Examining Division, United States Copyright Office, in Washington, D.C., Jan. 15, 1968.

62182 F. 150 (C.C.E.D. Pa. 1910), aff'd on other grounds, $191 \mathrm{~F} .35$ (3d Cir. 1911), aff'd, 235 U.S. 33 (1914).

63 Act of June 18, 1874, ch. 301,18 Stat. 957.

64182 F. 150 passim.

65 Id. at 152 .

6636 F.2d 727 (2d Cir. 1929).

67 Id. at 729.

68 See Pogue, Borderland-Where Copyright and Design Patent Meet, 52 Mice.

L. REv. 33, 50-51 (1953). 
however, it does not justify the broad exclusion of the regulations in question. Consistently with the holding in Korzybski, a person could preserve his claim to both monopolies simply by placing a copyright notice on his design or drawing before submitting it to the Patent Office, ${ }^{69}$ since publication with notice is sufficient to invest statutory copyright. ${ }^{70}$ Although filing a work not bearing the statutory notice in the Patent Office might well constitute a publication sufficient to divest common-law rights in the submitted work, ${ }^{71}$ and hence render copyright unobtainable, ${ }^{72}$ the rationale of Korzybski affords no basis for refusing to register a validly copyrighted work which is subsequently patented. ${ }^{73}$ Thus, the availability of dual protection would depend only upon which monopoly was obtained first.

69 This is because the Korzybski court rested its conclusion on the premise that filing the drawings of a patented invention in the Patent Office constitutes a divestive publication placing them in the public domain, so that they could not subsequently be copyrighted without violating the statutory prohibition against copyrighting anything in the public domain, 17 U.S.C. $\$ 8$ (1964). If the drawings were copyrighted prior to filing, there would be no contravention of this provision, and the rule of the case would not apply.

70 See note 2 supra.

71 Holding that filing in a governmental office constitutes such a divestive publication are Callaghan v. Myers, 128 U.S. 617 (1888); DeSilva Constr. Corp. v. Herrald, 213 F. Supp. 184 (M.D. Fla. 1962); Wright v. Eisle, 86 App. Div. 356, 83 N.Y.S. 887 (2d Dept. 1903) ; Tumey v. Little, 186 N.Y.S.2d 94 (Sup. Ct. 1959). Contra, United States v. Certain Parcels of Land, 15 F.R.D. 224 (S.D. Cal. 1954); Smith v. Paul, 174 Cal. App. 2d 744, 345 P.2d 546 (1959); Edgar H. Wood Associates v. Skene, 347 Mass. 351, 197 N.E.2d 886 (1964).

72 Publication without notice of copyright will inject a work into the public domain, at least if published by authority of the copyright proprietor. Atlantic Monthly Co. v. Post Publishing Co., 27 F.2d 556 (D. Mass. 1928); cf. McDaniel v. Friedman, 98 F.2d 745 (7th Cir. 1938).

73 The whole concept of "publication" in copyright law is imprecise, owing largely to the fact that the term is nowhere defined in the Copyright Act. One source of confusion is the distinction that has been drawn between "investive" and "divestive" publication. As noted in the two preceding footnotes, publication is necessary in order to invest an author with federal copyright protection (except in the case of works enumerated in 17 U.S.C. $\$ 12$ (1964), as to which copyright may be obtained upon deposit before publication); but publication of a work without the statutory notice will serve to divest common-law copyright and render statutory copyright unobtainable. In American Visuals Corp. v. Holland, 239 F.2d 740, 744 (2d Cir. 1956), Judge Frank concluded that

the courts apply different tests of publication depending on whether plaintiff is claiming protection because he did not publish and hence has a common law claim of infringement-in which case the distribution must be quite large to constitute "publication" -or whether he is claiming under the copyright statute-in which case the requirements for publication are quite narrow. In each case the courts appear so to treat the concept of "publication" as to prevent piracy.

Thus formulated, Judge Frank's doctrine may not be a particularly useful generalization, since it is stated in terms incapable of precise application. How large is "quite large," and how narrow is "quite narrow"? Nevertheless, other cases have approved or even extended the doctrine, albeit as dicta. See Public Affairs Associates v. Rickover, 284 F.2d 262 (D.C. Cir. 1960), vacated for insufficient record, 369 U.S. 111 (1962) ; Continental Cas. Co. v. Beardsley, 253 F.2d 702 (2d Cir. 1958); Hirshon v. United Artists Corp., 243 F.2d 640 (D.C. Cir. 1957) ; Burnett v. Lambino, 204 F. Supp. 327 (S.D.N.Y. 1962); Edgar H. Wood Associates v. Skene, 347 Mass. 351 , 197 i.E.2d 886 (1964). Whatever may be the limits of the doctrine, however, it does indicate that a publication sufficient to divest common-law rights would also be sufficient to invest statutory copyright. Applied to the Korzybski situation, this means that even if filing in the Patent Office should be held a sufficient publication of the work to divest common-law rights, as indicated by the cases cited in note 71 sipra, then a fortiori such filing of the work with notice of copyright would constitute sufficient publication to invest statutory copyright. 
The inconsistent results flowing from the narrow Korzybski theory have led at least one commentator to speculate that the regulations in question are based not on the holding in Korzybski, but rather on the "fundamentally sound view that the creator might have an election between the two forms of protection ${ }^{[74]}$... but that the federal protective scheme never intended double protection." 75 Such a view, however, is a flimsy base on which to ground an exclusionary regulation. Apparently recognizing the uncertainty of the "federal scheme" in this area, the same writer went on to observe that while such a restrictive approach to double protection might be most consistent with overall governmental policy toward monopolies, "it does not square easily with the ruling in Mazer $v$. Stein that there is an overlap between patentable and copyrightable subjects." 78

The argument that a work qualifying for either copyright or patent might be allowed to obtain both forms of protection certainly does not seem untenable. Although courts have generally been hostile to attempts to extend the length or scope of a statutory monopoly, ${ }^{77}$ it does not necessarily follow that the simultaneous grant of patent and copyright would bring about an undue extension of either monopoly. To a large extent, the interests protected by patent and copyright are different. Basically, the Patent Act grants a broad monopoly for a relatively short period (up to seventeen years), ${ }^{78}$ whereas the Copyright Act grants a considerably more restricted monopoly for a much longer period (up to fifty-six years). ${ }^{72}$ The holder of a patent may "exclude others from making, using, or selling the invention throughout the United States." so He is thus given a monopoly of the art disclosed by his patent application, that is, of the idea behind his invention. ${ }^{81} \mathrm{He}$ may prevent the exploitation of the invention not

74 See, e.g., Jones Bros. v. Underkoffler, 16 F. Supp. 729, 731 (M.D. Pa. 1936); Louis De Jonge \& Co. v. Breuker \& Kessler Co., 182 F. 150, 152 (C.C.E.D. Pa. 1910).

75 Nimetz, Design Protection, in 15 ASCAP, Copyright Law Symposium 79, 85 n.23 (1967).

78 Id. at 86 n.23.

77 See, e.g., Brulotte v. Thys Co., 379 U.S. 29 (1964).

7835 U.S.C. \$ 154 (1964) provides:

Every patent shall contain . . . a grant to the patentee, his heirs or assigns, for the term of seventeen years, subject to the payment of issue fees as provided for in this title, of the right to exclude others from making, using, or selling the invention throughout the United States, referring to the specification for the particulars thereof.

In the case of design patents, the applicant may elect a term of 3 years and 6 months, 7 years, or 14 years, depending upon the amount of fee paid. Id. $\$ \$ 171,41$ (a) (3) (b). 79 The Copyright Act provides for an original term of 28 years, renewable under certain conditions for a further term of 28 years. 17 U.S.C. \$24 (1964).

8035 U.S.C. $\$ 154$ (1964).

\$1 See, e.g., Flowers v. Austin-Western Co., 149 F.2d 955, 958 (7th Cir. 1945) :

[O]ne device is an infringement of another if it performs substantially the same function in substantially the same way to obtain the same result, so that if two devices do the same work, in substantially the same way and accomplish substantially the same result, they are the same, even though they differ in name, form or shape . . .

As another judge put it, "[A] "monopoly' [i.e., the patent monopoly] means the exclusion of others from doing the same or a similar thing ...." Hoffman v. Berger, 18 F. Supp. 632, 634 (S.D.N.Y. 1937). 
only by copiers, but also by another person who later "discovered" the same invention in perfect ignorance of the prior discovery. ${ }^{22}$ By contrast, the copyright holder is given only the right to multiply and sell copies of his ozen work. ${ }^{83}$ The quality protected by copyright is originality, not novelty or invention. ${ }^{84}$ In keeping with the more limited nature of the copyright monopoly, numerous cases have held that there can be no infringement unless the copyrighted work is actually copied. ${ }^{85}$ Thus, if two persons should independently create identical works of art, each could obtain the exclusive right to make copies of his own work without infringing the other's copyright. ${ }^{86}$

Because of the different interests protected by patent and copyright, there are relatively few works that conceivably could qualify for both forms of protection. The two types of works that most readily come to mind are those covered by the regulations criticized above: scientific or technical drawings which form part of a patent application, and works of art embodying sufficient novelty and invention to make them patentable. ${ }^{87}$

82 The later inventor would not be able to obtain a patent for his invention, if substantially similar to the prior one, because of the requirement of novelty imposed by 35 U.S.C. $\$ 102$ (1964). "The patentee must not only have originated the idea, but he must have been the first to have done so." Julius Kayser \& Co. v. Rosedale Knitting Co. 18 F. Supp. 836, 840 (E.D. Pa. 1937), aff'd, 98 F.2d 839 (3d Cir.), cert. denied, 305 U.S. 649 (1938). Put another way,"[G]enerally speaking, [the right of the first inventor of a patentable device or process to a patent therefor] may not be defeated by a subsequent inventor, or by the public, unless an abandonment of the right on the part of such first inventor be shown." Stresau v. Ipsen, 77 F.2d 937 (C.C.P.A. 1935).

8317 U.S.C. $\$ 1$ (1964) provides in part that:

Any person entitled thereto, upon complying with the provisions of this title, shall have the exclusive right:

(a) To print, reprint, publish, copy, and vend the copyrighted work;

The remainder of the section enumerates other rights of the copyrightholder, none of which are applicable to works of art or scientific or technical drawings.

84 Originality is both a constitutional and a statutory prerequisite to copyrightability. The copyright clause of the Constitution restricts the power of Congress in granting copyright protection to "authors." U.S. CoNST. art. 1, \& 8. The Supreme Court has defined "author" in the constitutional sense to be "[H]e to whom anything owes its origin; originator; maker." Burrow-Giles Lithographic Co. v. Sarony, 111 U.S. 53, 58 (1884). Thus, a person who has merely copied from others may not be deemed an author. Although the Copyright Act makes no express requirement of originality, courts have uniformly implied the requirement. See, e.g., Du Puy v. Post Telegram Co., 210 F. 883 (3d Cir. 1914) ; Edward Thompson Co. v. American Law Book Co., 122 F. 922 (2d Cir. 1903). This implication can be based on the limitation in 17 U.S.C. $\$ 9$ (1964) that copyright protection may only be claimed by "authors," or their successors in interest. See Gladys Music Inc. v. Arch Music Co., 150 U.S.P.Q. 26 (S.D.N.Y. 1966).

85 White-Smith Music Publishing Co. v. Apollo Co., 209 U.S. 1 (1908) ; Bleistein v. Donaldson Lithographing Co., 188 U.S. 239, 249 (1903) ; Alfred Bell \& Co. v. Catalda Fine Arts, Inc., 191 F.2d 99, 103 (2d Cir. 1951); Christie v. Cohan, 154 F.2d 827 (2d Cir. 1946) ; Arnstein v. Porter, 154 F.2d 464, 468-69 (2d Cir. 1946) ; Ansehl v. Puritan Pharmaceutical Co., 61 F.2d 131 (8th Cir. 1932).

86 Alfred Bell \& Co. v. Catalda Fine Arts, Inc., 191 F.2d 99 (2d Cir. 1951); Sheldon v. Metro-Goldwyn Pictures Corp., 81 F.2d 49, 54 (2d Cir. 1936), aff'd, 309 U.S. 390 (1940); Fred Fisher, Inc. v. Dillingham, 298 F. 145 (S.D.N.Y. 1924). See Reed v. Carusi, 20 F. Cas. 431 (No. 11,642) (C.C.D. Md. 1845).

87 Another type of work which would conceivably qualify for both types of protection is a print or label, which might either be registered under 17 U.S.C. $\$ 5(\mathrm{k})$ (1964), or submitted for a design patent under 35 U.S.C. \$171 (1964). See In re Blood, 23 F.2d 772 (D.C. Cir. 1927) (dual protection denied). 
The consequences of allowing dual protection to the first of these types may best be illustrated by an example. Suppose that the inventor of a radical new type of can opener wishes to copyright the technical drawings disclosing the invention. Before submitting them to the Patent Office, he places on them the statutory notice of copyright. Assume that the drawings will be sufficiently published when filed to invest the copyright under section 10 of the Copyright Act. ${ }^{88}$ Then if a patent subsequently issues on the invention disclosed by the drawings, during the patent term the copyright will add little to the exclusive rights granted by the patent, for by the terms of the patent no one may make, use, or sell the invention without first obtaining a license from the patentee. ${ }^{89}$ The only right conferred by the copyright that is not granted under the patent is the exclusive right to copy the drawings. The added coverage would mean that, for example, a person who wished to publish a treatise on the art of making can openers, illustrating his text with the copyrighted drawings, would have to pay royalties to the copyright holder. This slight additional burden would not seem sufficient reason to deny copyright protection.

As part of the consideration for the grant of the patent monopoly, however, when the patent expires the invention disclosed therein is supposed to become freely exploitable by the public. ${ }^{90}$ If the copyright in the drawings were to interfere with free exploitation, it would have the difficult-to-justify effect of prolonging the patent monopoly. It is unlikely, however, that the continuing existence of the copyright would in fact create such interference. Control of the right to publish the drawings would in no way prevent anyone from using them as an aid in manufacturing the can opener, since the Copyright Act confers no monopoly of use. Nor, by the weight of authority, would the manufactured article constitute an infringing "copy" of the drawings. ${ }^{01}$

88 See note 73 sipra.

8935 U.S.C. $\$ 154$ (1964).

90 Brulotte v. Thys Co., 379 U.S. 29, 31 (1964) ; Kellogg \& Co. v. National Biscuit Co., 305 U.S. 111, 118 (1938) ; Singer Mfg. Co. v. June Mfg. Co., 163 U.S. 169 , 185 (1896). As stated by the Court in Scott Paper Co. v. Marcalus Mfg. Co., 326 U.S. 249, 255-56 (1945) :

By the patent laws Congress has given to the inventor opportunity to secure the material rewards for his invention for a limited time, on condition that he make full disclosure for the benefit of the public of the manner of making and using the invention, and that upon the expiration of the patent the public be left free to use the invention... . [T] me means adopted by Congress of promoting the progress of science and the arts is the limited grant of the patent monopoly in return for full disclosure of the patented invention and its dedication to the public on the expiration of the patent. . .

-.. [A]ny attempted reservation or continuation in the patentee or those claiming under him of the patent monopoly, after the patent expires, whatever the legal device employed, runs counter to the policy and purpose of the patent laws.

91 The subject of the drawings, a can opener, is by hypothesis not copyrightable, being neither a work of art (Class G) nor a plastic work (Class I). Copyright in the drawings will therefore protect only against reproduction of the drawings, not against copying of the can opener per se, as distinguished from the original elements (angle, 
With respect to the second category of works potentially eligible for dual protection, works of art, there would seem to be no greater reason to prohibit the coexistence of the two monopolies. Assume that an extraordinarily talented craftsman has created a new design for a saltcellar. The design is sufficiently novel and inventive to qualify for a design patent, yet the finished product looks so much like a modern sculpture that it is unquestionably a work of art and copyrightable as such. ${ }^{92}$ Copyright would protect the artistic features of the work as expressed in the particular form of the finished product; design patent would protect whatever new principle or idea had been embodied in the design. ${ }^{93}$ Once the design patent had expired, others would be free to use this idea or principle with impunity in whatever way they might wish, so long as they did not copy the particular form of artistically expressing that principle embodied in the copyrighted saltcellar. Thus, for the balance of the copyright term, the designer would have no greater rights than he would have had if the design patent had never issued; he could not use the copyright to monopolize his new principle of saltcellar design, since others would be free to use that principle so long as their saltcellars did not resemble his so closely as to warrant an inference of actual copying.

Responding to the above or similar arguments, a court might not unreasonably find it consistent with Congress's overall statutory scheme to allow both patent and copyright in different aspects of the same work, and thus uphold a copyright claim in drawings forming part of an issued patent or in a work of art on which a design patent had already been obtained. Such a finding seems all the more likely in the light of the Supreme Court's refusal to rule out the possibility of dual protection in Mazer $v$. Stein. ${ }^{94}$ Given the absence of an authoritative judicial opinion or statute clearly holding dual protection unavailable, the regulations denying registration to such copyright claims are clearly not formulated with due regard to the rule of doubt

perspective, etc.) contained in the drawings qua drawings. Cf. Modern Aids, Inc. v. R. H. Macy \& Co., 264 F.2d 93 (2d Cir. 1959).

It should be noted, however, that if the subject of the drawings were itself copyrightable (e.g., a toy registrable as a work of art), then the protectable elements in the drawings or illustrations would include not only the manner of depicting the toy in two-dimensional form, but also the form and appearance of the toy itself. If these protectable elements should in turn be incorporated into a three-dimensional toy copied from the drawings, the latter would be an infringing copy. Fleischer Studios, Inc. v. Ralph A. Freundlich, Inc., 73 F.2d 276 (2d Cir. 1934); King Features Syndicate v. Fleischer, 299 F. 533 (2d Cir. 1924). See also Hene v. Samstag, 198 F. 359 (S.D.N.Y. 1912). But cf. E. I. Horsman \& Aetna Doll Co. v. Kaufman, 286 F. 372 (2d Cir.), cert. denied, 261 U.S. 615 (1922).

92 In Class G. 17 U.S.C. $\$ 5(\mathrm{~g})$ (1964).

93 This dichotomy of protection would hold true so long as form was not so bound up with function as to make the two inseparable. But if form were dictated solely by function, it is unlikely that the Register would accept the article for registration. See Copyright Office Regulations, 37 C.F.R. $\$ \$ 202.10$ (a), (c) (1967) ; discussion in text accompanying notes 123-136 infra.

24347 U.S. 201 (1954). 
or to the policies which prompt that rule: they foreclose copyright in works in which copyright might well be upheld by the courts. ${ }^{95}$

\section{Regulations Unduly Limiting the Registrability of $a$ Class of Works}

The correctness of the Register's decision not to issue certificates of registration in the circumstances just discussed is clearly open to question. Some regulations, however, are more ambiguous, as for example, those concerning choreographic works. The policies governing the registrability of such works are of uncertain scope, as well as of doubtful validity.

The copyright statute makes no explicit mention of choreographic works as such; yet, in order to receive copyright protection, they must be classified under one of the statutory rubrics of section $5 .^{96}$ The most appropriate of these is Class $D$ (dramatic or dramatico-musical compositions). Although the notation for a choreographic work might be registered in another class, ${ }^{97}$ only Class $D$ affords the copyright holder protection against unauthorized public performance of the work, ${ }^{98}$ which in the case of choreographic works is at once the most likely and, potentially, the most damaging type of infringement. ${ }^{99}$ The current regulation governing Class $D$ permits the registration of

95 No decision expressly granting such double protection has been found, but it was at least countenanced in Wilson v. Haber Bros., 275 F. 346 (2d Cir. 1921). The court allowed recovery for infringement of both a copyright and a design patent on a kewpie doll, although it did not pass on the question of the validity of double protection since the defendant had estopped himself from contesting this issue by a prior consent decree. But see In re Blood, 23 F.2d 772 (D.C. Cir. 1927) (application for design patent denied on hosiery ticket which had obtained copyright registration as a label); Ex parte Guild, 98 U.S.P.Q. 464 (Pat. Off. B. A. 1952), aff'd on other grounds, 204 F.2d 700 (C.C.P.A. 1953) (application for design patent denied on roof design which had obtained copyright registration as a work of art).

86 Despite the fact that $\$ 4$ of the 1909 Act states that "[t] he works for which copyright may be secured under this title shall include all the writings of an author," and $\$ 5$ provides that " $[t]$ he above specifications [i.e., the enumerated classes of copyrightable works] shall not be held to limit the subject matter of copyright as defined in $\$ 4$ of this title..." no case has been found to uphold a copyright in an item that could not be fitted into one of the classes mentioned in $\$ 5$. In Capitol Records, Inc. v. Mercury Records Corp., 221 F.2d 657 (2d Cir. 1955), the court construed the Copyright Act so as to restrict "writings" protected by $\$ 4$ of the Act to a more limited class of items than all works which are capable of protection under the Constitution.

77 E.g., Class A (books); Classes L-M (motion pictures). 17 U.S.C. \$§ 5(a), (l), (m) (1964).

98 Section 1(d) of the 1909 Act grants the copyright proprietor the exclusive right "[t]o perform or represent the copyrighted work publicly if it be a drama . . . and to exhibit, perform, represent, produce, or reproduce it in any manner or by any method whatsoever." 17 U.S.C. §1(d) (1964).

99 See letter from Agnes George DeMille, reprinted in B. VARMrer, Copyright in Choreographic Works, Study No. 28, 86th Cong., 2d Sess. 110 (Comm. Print 1961). But see letter from Lincoln Kirstein, $i d$. at 113 , suggesting that the expense of reducing a ballet to legible notation (roughly $\$ 1200$ for 20 minutes), together with the difficulty of reproducing the work from the notation alone, cause the benefits to be reaped from obtaining copyright protection for choreographic works to be outweighed by the trouble and expense involved. 
choreographic works in this class if they are "of a dramatic character, whether the story or theme be expressed by music and action combined or by actions alone." 100 The same regulation goes on to exclude from Class D registration, however, "descriptions of dance steps and other physical gestures, including ballroom and social dances or choreographic works which do not tell a story, develop a character or emotion, or otherwise convey a dramatic concept or idea." 101

This regulation obviously attempts to draw a distinction between those choreographic works that are "dramatic" and those that are not. Such a distinction is admittedly necessary under the statute, for if a ballet is to qualify as a "dramatic work," by definition it must have some dramatic quality. The problem lies in defining that quality, and this is a question of import to choreographers. Most traditional ballets depict a story or narrative through the actions of the dancers and therefore clearly fall within the category of "dramatic works" both under the regulations and under the cases. ${ }^{102}$ Many modern dances, however, are to dance as abstract expressionism is to painting: they explore movement and form, tell no story, and may convey no identifiable character or emotion. If an emotion is conveyed to the audience, it is likely to be wholly subjective, incapable of a generalized definition or description. ${ }^{103}$

10037 C.F.R. $\$ 202.7$ (1967).

101 Id.

102 Several early cases are generally cited for the proposition that in order for : composition to be considered a dramatic composition under the Copyright Act, it must tell a story. The authority most widely relied on is Fuller v. Bemis, $50 \mathrm{~F}$. 926 (C.C.S.D.N.Y. 1892), which involved a claim of copyright in a description of the movements of a stage dance. As the court characterized the dance, it "convey [ed] to the spectator, no other idea than that comely woman is illustrating the poetry of motion in a singularly graceful fashion." Id. at 929. In denying a preliminary injunction to the plaintiff, the court stated, "It is essential to such a composition that it should tell some story. The plot may be simple. . . . The merely mechanical movements by which effects are produced on the stage are not subjects of copyright where they convey no ideas whose arrangement makes up a dramatic composition." Id. There is some ground for supposing, however, that the real basis for decision was that the court felt the dance to be risque or even immoral. See the description of the dance set out at 50 F. 926-27. See also Mirell, Legal Protection for Choreography, 27 N.Y.U. L. REv. 792, 807-09 (1952). Two other cases also deny copyright protection as a dramatic work on similar grounds: Martinetti v. Maguire, 16 F. Cas. 920 (No. 9173) (C.C. Cal. 1867), and Barnes v. Miner, 122 F. 480 (C.C.S.D.N.Y. 1903). Both cases, however, seem even more clearly to rest on the unspoken ground of immorality. See Mirell, supra, at 807-09. But see Daly v. Palmer, 6 F. Cas. 1132, 1135-36 (No. 3552) (C.C.S.D.N.Y. 1868), in which a stage presentation involving a single incident of rescue was held copyrightable as a "dramatic composition." See also Hendersen v. Tompkins, 60 F. 758 (C.C.D. Mass. 1894) (public performance using idea and lyrics of plaintiff's song held a copyrightable dramatic composition); Green v. Luby, 177 F. 287 (C.C.S.D.N.Y. 1909) (sketch consisting of recitations and songs, with very little dialogue and action, held a dramatico-musical composition within the Copyright Act).

103 Cf. Letter from Lincoln Kirstein reprinted in B. VARMER, Copyright IN Choreographic Works, Study No. 28, 86th Cong., 2d Sess. 113 (Comm. Print 1961) : Increasingly, ballets fail to tell stories. They are about the dance itself, just as symphonic music is about sound. Some critics attach programs of the 'March of Fate' or the 'Triumph of Love' to a piece but this is merely a point of departure to their prose-poems and has little to do with the ballet, itself. 
The registrability of such a work is left in doubt by the regulation quoted above, and there is little available precedent to elucidate the standard therein set forth. Yet a reasonable case can be made for the proposition that any choreographic work designed to evoke a reaction in its audience through the actions of one or more dancerswhether the reaction be emotional or purely intellectual-should be considered "dramatic," and hence entitled to copyright. It may be that the phrase "otherwise convey a dramatic concept or idea" ${ }^{104}$ is broad enough to encompass even the most abstract of choreographic works, but it seems doubtful that the Copyright Office does in fact give the phrase such an interpretation, especially in view of the Office's announced requirement that in order to be eligible for registration as an unpublished work, a copy of the choreographic work which is "merely diagrammatic of dance movement and actions (for example, if it is in Labanotation), . . . be accompanied by a verbal description of the production as a whole, explaining the plot, characters, themes, or emotions expressed by the choreography." 105 Under this rule, a work that is so abstract that it expresses no theme or emotion, let alone plot or character, is thus excluded from registration even though it could legitimately be considered "dramatic." One can only conclude that the rule of doubt has not been given sufficient scope with respect to this type of work..$^{108}$

\section{Regulations Permitting the Register to Exercise Too Great a Degree of Subjective Judgment in Deciding What Is Copyrightable}

The regulations just discussed embody the Register's advance decision to deny registration to certain fairly well-delineated categories of works, despite the fact that their copyrightability might conceivably be upheld by the courts. There is another series of regulations under

10437 C.F.R. $\$ 202.7$ (1967).

105 Copyright Office Circular No. 51 "Choreographic Works." This requirement could, of course, be quite easily circumvented, since it would be a simple matter for the author of the work to make up a verbal description of the production that would be sufficient on its face to gain approval by the examiners. This does not mean that the rule is harmless, however, since it may force the author to lie about his work on pain of being denied registration.

108 There is some uncertainty as to how rigidly the Copyright Office intends to enforce the requirement mentioned in the preceding footnote. Mirell, supra note 102 , at 810-811, relates that registration in Class D was obtained for the choreographic score (in Labanotation) of the musical "Kiss Me, Kate," although the dances were "mood and idea pieces, devoid of plot or story in the usual sense." Id. at 810. The score itself revealed no plot or story line, nor did any of the material accompanying the score. But the concession may have been more apparent than real, for an interoffice memorandum regarding this registration stated that the applicant had " purported to fulfill the ... conditions for registration of a work as a dramatic composition; that is, the indicated dance movements spelled out, to a person familiar with the system, a story told in action, marked by the prescribed boundaries of a particular stage or setting." "United States Copyright Office interoffice memorandum regarding the registration of Miss Hanya Holm's dances for "Kiss Me, Kate," March 1952, quoted in Mirell, supra note 102 , at 811 n.86. 
Class G (works of art), however, which calls for the exercise of so great a degree of subjective judgment on the part of the Register in deciding what works are copyrightable that the claimant runs at least an equal risk of an unjustified denial of registration. This judgment is brought to bear in two successive determinations: first, whether the work in question is sufficiently creative to meet the minimum standard for copyrightability; and second, whether any mechanical or utilitarian aspect the article may possess bars it from being considered a work of art.

All works listed in section 5 must possess a certain minimal amount of creativity in order to be copyrightable, ${ }^{107}$ in addition to the requirement that they represent an independent effort ("originality") on the part of their authors. ${ }^{108}$ This requirement applies to works of art in a qualitatively different manner, however, than it does to the other enumerated classes of works. As Professor Nimmer has pointed out:

[A] photograph even if completely lacking in creativity is still undeniably a photograph if in its form it is the product of the photographic process. Similarly a book, a map, a musical composition or any of the other types of works enumerated in Sec. 5 of the Copyright Act are identifiable and definable by the nature of their respective forms regardless of whether such forms evidence any creativity . . . . With respect to works of art, however, the requirement of minimal creativity is applied . . . as a matter of definition. That is, unless a work evidences "some creative authorship in its delineation or form" it cannot by definition be regarded as a work of art. ${ }^{109}$

In other words, if someone properly submits a photograph for registration, all the Register need do is determine that the submitted item is in fact a photograph, and therefore registrable in Class $\mathrm{J}$, a matter which ordinarily requires no exercise of discretion. Any question whether the photograph is sufficiently creative to be copyrightable need not be decided by the Register, but can be left for a court to

107 Illustrative of this requirement are cases denying copyright protection to fragmentary words or phrases, see, e.g., Smith v. George E. Muehlebach Brewing Co., 140 F. Supp. 729 (W.D. Mo. 1956); Kanover v. Marks, 91 U.S.P.Q. 370 (S.D.N.Y. 1951); to non-creative variations of musical compositions, see, e.g., Norden v. Oliver Ditson Co., 13 F. Supp. 415 (D. Mass. 1936); and to forms of expression dictated solely by functional considerations, see, e.g., Caddy-Imler Creations, Inc. v. Caddy, 299 F.2d 79 (9th Cir. 1962) ; Consumer Union of United States, Inc. v. Hobart Mfg. Co., 199 F. Supp. 860 (S.D.N.Y. 1961) (compilation of factual material) ; E. H. Tate Co. v. Jiffy Enterprises, Inc., 16 F.R.D. 571 (E.D. Pa. 1954) (instructions for use of hanger); $c f$. Dietrich v. Standard Brands, Inc., 32 F.R.D. 325 (E.D. Pa. 1963); 37 C.F.R. \$202.1(d) (1967). See generally M. NimMer, CopyrigrT $\$ 10.2$ (1967).

108 See note 84 sipra.

109 M. NIMMER, supra note $107, \S 19.1$, at 85 (quoting 37 C.F.R. $\$ 202.10$ (b) (1967)) (footnote omitted). 
settle in future litigation. On the other hand, when an item is submitted to the Register for registration as a work of art, he must exercise discretion in deciding whether or not to accept it as such.

It is in this context that the Register must appraise the creativity of the work. A very low level of creativity will suffice, ${ }^{110}$ but it is clear that there are broad limits beyond which the courts will not accord recognition as a work of art; these limits also define the outer boundaries of his discretion. One test of creativity was presented in Bailie v. Fisher, ${ }^{111}$ where the claimant sought to compel the Register to issue a certificate of registration for a five-pointed cardboard star with a circular center, designed to receive a photograph of a movie star. The court agreed with the Register that this device did not constitute a work of art. ${ }^{112}$

To illustrate this problem further, consider the case of an artist who wishes to register as a work of art a perfectly round, smooth and unornamented metal sphere which he has formed by melting lead and pouring it into a mold. It is difficult to see how this could embody sufficient creativity to qualify even under the most generous standard a court might apply, so the Register would be justified in refusing to issue a certificate. But suppose that the artist remelts his ball of lead, this time flattening it a bit to make it slightly pear-shaped. How is the Register to decide whether or not the form of the lead now embodies sufficient creativity to have been transformed from a publicdomain sphere into a work of art? Similarly, a simple drawing of a square clearly would not embody sufficient creativity-but let the square be transferred to canvas, appropriately placed and set off by a contrasting background, and an arguably copyrightable work of art has been created.

Even when the submitted article possesses sufficient creativity, however, it still must surmount a second hurdle, namely a deter-

110 The still-prevailing rule was stated by Mr. Justice Holmes in the landmark case of Bleistein v. Donaldson Lithographing Co., 188 U.S. 239 (1903) :

It would be a dangerous undertaking for persons trained only to the law to constitute themselves final judges of the worth of pictorial illustrations, outside of the narrowest and most obvious limits. At the one extreme some works of genius would be sure to miss appreciation. Their very novelty would make them repulsive until the public had learned the new language in which their author spoke. It may be more than doubted, for instance, whether the etchings of Goya or the paintings of Manet would have been sure of protection when seen for the first time. At the other end, copyright would be denied to pictures which appealed to a public less educated than the judge. Yet if they command the interest of any public, they have a commercial value-it would be bold to say that they have not an aesthetic and educational valueand the taste of any public is not to be treated with contempt. It is an ultimate fact for the moment, whatever may be our hopes for a change.

Id. at 251-52.

111258 F.2d 425 (D.C. Cir. 1958).

112 The court adopted the test proposed by the Ninth Circuit, leaving the Register broad discretion: "A thing is a work of art... if it appears to be within the historical and ordinary conception of the term art." Id. at 426, quoting Rosenthal v. Stein, 205 F.2d 633, 635 (9th Cir. 1953). 
mination by the Register that its "sole intrinsic function" is not its "utility." 113 This requirement stems from the fear, reflected by the Supreme Court's decision in the early case of Baker $v$. Selden, ${ }^{114}$ that if copyright were permitted in works whose primary function is their utility, a monopoly would thereby be indirectly granted "not only of the use of the copyrighted work itself, but also of the system, function, process or art (i.e. the 'idea') upon which the work is based or for which it is fitted." 115 While the indirect monopoly of use of the copyrighted article would not of itself necessarily be contrary to the statutory scheme, ${ }^{116}$ if this indirect monopoly were to extend to the science underlying the work, then copyright could be used to circumvent the stricter requirements of patent law by granting protection to ideas, which are specifically excluded from copyright protection. ${ }^{117}$ The resultant rule, ${ }^{118}$ as reflected in the regulations, leaves an ill-defined line between works of art and works of utility. To the former, the Register must issue a certificate; to the latter, he must deny it. But since there is little case law on the distinction between the two, ${ }^{119}$ the Register's discretion is virtually unbridled.

The Register's task has been further confused by the holding of the Supreme Court in Mazer v. Stein ${ }^{120}$ that there is an overlap between the fields of patent and copyright, and that certain articles may qualify for either type of protection, if not both. ${ }^{121}$ The Mazer case, an action for infringement of copyright, raised the issue whether plaintiff's copyright in a statuette - considered a work of art by itself-was invalidated by the subsequent utilization of or intention to utilize copies of the statuette as a base for lamps manufactured by plaintiff, defendant having made highly accurate copies of the lamps, including the statuettes. The Court held the statuettes to be validly copyrightable with or without the lamp fixtures, saying: "We find nothing in the copyright statute to support the argument that the intended use or use in industry of an article eligible for copyright bars or invalidates its registration." 122 In so holding, the Court expressly approved the Copyright Office regulation which includes under section $5(\mathrm{~g})$ "works

11337 C.F.R. $\$ 202.10$ (c) (1967).

114101 U.S. 99 (1880).

115 M. NIMAser, supra note 107, §37.1, at 148.

116 See id.

117 See text accompanying notes 77-95 supra.

118 Professor Nimmer doubts the need for such a rule, since a copyright only empowers the author to prevent direct copying of his work, not the application or restating of any functional system contained therein. See M. NIMMER, supra note 107, at $\$ 37.4$.

119 See text accompanying notes 59-65 supra.

120347 U.S. 201 (1954).

121 See text accompanying notes 66-95 supra, where the possibility of simultaneously obtaining copyright and patent protection is discussed.

122347 U.S. at 218. 
of artistic craftsmanship, insofar as their form but not their mechanical or utilitarian aspects are concerned." 123

It has thus been established that the use to which a separately identifiable work of art is put will not affect its copyrightability. In many objects, however, artistic or ornamental features are found combined with functional features in such a way that the two are not readily separable. This is true, for example, of an enameled ashtray, a jeweled pin or an engraved glass vase. How is the Register to decide whether a work has artistic form apart from what its mechanical or utilitarian aspects demand? For example, jewelry can be copyrighted, ${ }^{124}$ while an ordinary watch clearly cannot, since the form of a watch is dictated by its function, rather than by artistic expression. But what of a highly bejeweled watch? In the Vacheron case, ${ }^{125}$ plaintiff sued for the infringement of its copyright in such a watch, having obtained a design patent, but having been refused registration for a copyright as a "work of art." The distinctive feature of the watch was the jeweled appearance of its face, which differed from most men's watch faces in two respects: it bore twelve oblong jewels in place of numerals, and instead of hands it had two transparent rotating disks, each bearing a jewel mounted on its periphery. Resting its decision primarily on the ground that the sole function of the watch was its utility, the district court upheld the Register's refusal to issue a certificate. ${ }^{128}$ The court reached its decision notwithstanding its observation that the watch in some ways resembled jewelry: "[T]he effect of plaintiff's grouping of the elements of the design did create a watch with the appearance of a piece of jewelry as distinguished from a watch embellished with jewels." 127

The watch in Vacheron is representative of the objects with regard to which the Register must attempt to formulate and apply regulations that will define the line between a copyrightable work of art and an uncopyrightable article of utility. Although he denied registration to the watch, he has allowed it, with subsequent judicial approval, for such items as designs printed upon dress fabrics, ${ }^{128}$ dinnerware patterns, ${ }^{129}$ dolls, ${ }^{130}$ Christmas decorations, ${ }^{131}$ banks in the

12337 C.F.R. $\$ 202.10$ (a) (1967).

$124 I d$. The copyrightability of ornamental jewelry was upheld in Boucher v. Du Boyes, Inc., 253 F.2d 948 (2d Cir. 1958).

125 Vacheron \& Constantin-Le Coultre Watches, Inc. v. Benrus Watch Co., 155 F. Supp. 932 (S.D.N.Y. 1957), aff'd in part and rev'd in part, on other grounds, 260 F.2d 637 (2d Cir. 1958).

126155 F. Supp. at 934.

127 Id. at 935 .

128 See Peter Pan Fabrics, Inc. v. Brenda Fabrics, Inc., 169 F. Supp. 142 (S.D.N.Y. 1959).

129 See Syracuse China Corp. v. Stanley Roberts, Inc., 180 F. Supp. 527 (S.D. N.Y. 1960).

i30 See Rushton v. Vitale, 218 F.2d 434 (2d Cir. 1955) ; cf. Fleischer Studios, Inc. v. Ralph A. Freundlich, Inc., 73 F.2d 276 (2d Cir. 1934). 1961).

131 See Doran v. Sunset House Distrib. Corp., 197 F. Supp. 940, 945 (S.D. Cal. 
shape of $\operatorname{dogs}{ }^{132}$ and artistic jewelry boxes. ${ }^{133}$ Other items accepted for registration but not as yet tested in the courts include "book ends, clocks, lamps, door knockers, candlesticks, inkstands, chandeliers, piggy banks, sundials, salt and pepper shakers, fish bowls, casseroles, and ash trays." 134

Whether all of these would now be accepted for registration is somewhat doubtful, however, since in 1954 a new section was added to the Copyright Office Regulations, providing:

If the sole intrinsic function of an article is its utility, the fact that the article is unique and attractively shaped will not qualify it as a work of art. However, if the shape of a utilitarian article incorporates features, such as artistic sculpture, carving, or pictorial representation, which can be identified separately and are capable of existing independently as a work of art, such features will be eligible for registration. $^{135}$

While this regulation does clarify the criteria for acceptance as a work of art, it leaves in doubt the standard which will be applied in determining when an article has no other "intrinsic function" than "its utility." Could the creator of a casserole dish establish that it had an artistic function by producing half a dozen bishops to testify that they customarily displayed his creation in their living rooms? How is the Register to determine whether a feature can be "identified separately" and "exist independently as a work of art"? To the extent that the Register's determinations regarding status as a work of art involve primarily matters of opinion, rather than factual or legal determinations, they are necessarily subjective. When one recalls the function of the registration certificate, ${ }^{136}$ whose issuance or denial is thus made to depend upon such subjective judgments, one can see how great is the importance of providing some form of review of the Register's discretion.

\section{Undue Restrictions on Registrability Owing to Failure of Regulations to Respond Quickly to Changed Conditions}

In addition to the fact that some of the regulations define the field of available copyright either too narrowly or too broadly, leaving

132 See Royalty Designs, Inc. v. Thrifticheck Serv. Corp., 204 F. Supp. 702 (S.D.N.Y. 1962). 1962).

133 See Dan Kasoff, Inc. v. Gresco Jewelry Co., 204 F. Supp. 694 (S.D.N.Y.

134 Mazer v. Stein, 347 U.S. 201, 221 (1954) (separate opinion of Douglas, J.). See Staff Members of New York University Law Review, The Meaning of "Writings" in the Copyright Clause of the Constitution in 1 STUdIES ON CopYrigHT (1963). 13537 C.F.R. $\$ 202.10$ (c) (1967).

136 I.e., that it is a prerequisite to bringing an action for infringement and also has certain other advantages. See notes $29-34$ supra and accompanying text. 
much to the unguided discretion of the Register, there is a second factor exemplifying the need for easily obtainable review of the Register's decisions. This factor is the tendency of the Copyright Office to delay amending its regulations to correspond to changed needs and conditions, and even to new laws. Such a tendency is observable especially with regard to choreographic works and works of applied art.

If Diaghilev had sought copyright registration for one of his ballets in 1910, ${ }^{137}$ when the first regulations under the 1909 Act were promulgated, he would have been disappointed, for the regulations then provided that " $[t]$ he designation 'dramatic composition' does not include the following: Dances, ballets, or other choreographic works." 138 By 1917 his chances might have improved somewhat, for although the regulations made no positive mention of ballets or choreographic works, only "dances" were retained as a specific exclusion from "dramatic compositions." 139 In the 1939 regulations, there was still no positive mention of choreographic works or ballets, but "dances" continued to be excluded together with, inter alia, "animal shows, sleight-of-hand performances, and acrobatic or circus tricks of any kind." 140 It was not until 1948 that pantomimes and ballets were specially included in the regulations under Class D..$^{141}$

The copyrightability of works of applied art has had a similar development. Before 1909, copyright in works of art was limited to specific branches of the fine arts and models or designs intended to be perfected as works of the fine arts. ${ }^{142}$ By the Act of March 4, 1909, this category became simply "works of art; models or designs for works of art," as it remains to this day. ${ }^{143}$ For some time, however, the regulations under the 1909 Act preserved the distinction which had semingly been abandoned by the statute, stating under "works of art":

137 Conceivably he might have done so. Although the system of dance notation known as Labanotation, now the only universally recognized system, was not invented until 1928, other systems (albeit somewhat crude) did exist in 1910. One of these, perhaps coupled with a verbal description of the ballet, might well have supplied a sufficient written record of the work to qualify it for copyright.

138 Rules and Regulations for the Registration of Claims to Copyright, Copyright Office Bull. No. 15, at 7 (1910).

139 Rules and Regulations for the Registration of Claims to Copyright, Copyright Office Bull. No. 15, at 8 (1917).

14037 C.F.R. $\$ 201.4$ (c) (4) (1939).

14113 Fed. Reg. 8650 (1948). Unofficially, the Copyright Office has expressed the opinion that '[d] ramatic 'pantomimes' and 'ballets' were probably registrable ever since that Act [the Act of August 18, 1856, ch. 169, 11 Stat. 138, which was the first act to make dramatic compositions copyrightable] became the law . ..." Letter from the Copyright Office to Leon Mirell, Dec. 13, 1951, in Mirell, Legal Protection for Choreography, 27 N.Y.U. L. REv. 792, 803 n.52 (1952).

142 In 1873, copyright protection was granted, inter alia, to any "painting, drawing, chromo, statue, statuary, and ... models or designs intended to be perfected as works of the fine arts ...." Rev. Stat. $\$ 4952$ (1873). 
This term includes all works belonging to the so-called fine arts. (Paintings, drawings and sculpture.)

Productions of the industrial arts utilitarian in purpose and character are not subject to copyright registration, even if artistically made or ornamented. ${ }^{\mathbf{1 4 4}}$

The 1917 regulations retained intact the first paragraph of this definition but timidly observed that although

protection for productions of the industrial arts utilitarian in purpose and character even if artistically made or ornamented depends upon the patent law, . . . registration in the Copyright office has been made to protect artistic drawings notwithstanding they may afterwards be utilized for articles of manufacture. ${ }^{145}$

Noting the discrepancy between the regulations and the statute, one commentator has observed that "[a]lthough these regulations were open to the criticism that they ignored the spirit of the changes made by the Act of 1909, the Copyright Office operated on the premise that design patent and copyright should and could be separated." 146 Whatever the reasons for the Copyright Office's adherence to the policy that "works of art" meant "works of the fine arts," 147 it was not until 1948, nearly forty years after the passage of the 1909 Act, that the regulations were changed to permit copyrighting of works of art that contemporaneously possessed utilitarian features. ${ }^{148}$

Despite these reluctant adjustments to changing conditions, in recent years the Register has shown himself to be progressive in other matters of registration. He has accepted registrations of video tapes ${ }^{149}$ and computer programs, ${ }^{150}$ both of these being works whose

144 Rules and Regulations for the Registration of Claims to Copyright, Copyright Office Bull. No. $15, \S 12(\mathrm{~g})$ at $8(1910)$.

145 Rules and Regulations for the Registration of Claims to Copyright, Copyright Office Bull. No. 15, § 12(g), at 8-9 (1917).

146 Pogue, Borderland-Where Copyright and Design Patent Meet, 52 Mrcm. L. REv. 33, 44 (1953).

147 The case of Bleistein v. Donaldson Lithographing Co., 188 U.S. 239 (1903), discussed in note 110 supra, did not necessarily dictate a contrary policy. That case merely held that a lithographed circus poster, admittedly in the category of works belonging to the fine arts, could not be denied copyright either on the ground that it was of poor artistic quality or that it constituted "commercial" art.

148 In 1948 the first paragraph of the regulation under Class G (works of art) was amended (13 Fed. Reg. 8650 (1948)) to read substantially as it does today, 37 C.F.R. $\$ 202.10$ (a) (1967).

149 The first registration of a video tape recording was made on April 19, 1961, in Class L (motion-picture photoplays). Letter from Richard Colby to Professor Walter J. Derenberg, April 28, 1961, in 8 Bull. Copyright Soc'y 205 (1961).

150 The Copyright Office has expressed the conditions under which registration for computer programs will be considered in Copyright Office Cir. 31D (1965). The Office first announced that it would accept applications for registration of computer programs as such in April, 1964. 67 Regrster of Copyrights ANN. Rep. 4 (1965). 
copyrightability under the present statute is quite dubious. ${ }^{151}$ Nevertheless, there is ever present the possibility that the Register will fail to respond to a new need for copyright registration even though the statute can be interpreted to give him power to do so. Furthermore, there is no guarantee that the present relatively liberal attitude toward registration will not one day regress to a much more restrictive interpretation of the statute, thereby seriously impairing the protection available to persons creating works on the fringes of copyrightability.

\section{A Proposed Remedy : Direct Judicial Review of the RegisteR's REFUSAL to REgister}

The foregoing demonstrates that the "rule of doubt" policy ${ }^{152}$ as applied by the Register has not been sufficient to ensure that only claims which are clearly without merit will be denied registration. It is perhaps to be expected that he would tend to undershoot rather than overshoot the mark, despite his announced policy of giving the applicant the benefit of the doubt, ${ }^{153}$ and generally allow registration in doubtful instances only when the case for registration is quite substantial. Given this situation, some form of review for rejected applications short of bringing an action of mandamus against the Register is clearly warranted. The question is what form of relief can be provided to fill this need without unduly disrupting the existing system. Little purpose would be served by stripping the Register of his discretion to decline to issue a certificate, as has sometimes been proposed. ${ }^{154}$ Such a solution would deprive the registration system of its useful function of weeding out wholly worthless claims, as well as rendering virtually worthless the evidentiary presumption of validity accorded the certificate by section 209 of the Copyright Act. ${ }^{155}$ A better approach would be to work out a means of allowing the Register to sift out worthless claims, while at the same time permitting the victim of an unwarranted rejection to obtain prompt redress. The present system adequately achieves the first goal, but it leaves the

In that year, 3 registrations were made. $I d$. The number is growing, however; in fiscal 1965, 16 claims covering computer programs were registered, 68 REGISTER of Copyrights ANn. Rep. 4 (1966), and 36 in fiscal 1966. 69 Register of Copyrights ANN. REP. 5 (1967).

151 With respect to registration of both video tapes and computer programs, the principal doubts are (1) whether or not the work is a "writing" within the meaning of the copyright clause, U.S. CoNsT. art. $1, \S 8 ;(2)$ if so, whether it is encompassed by $\$ \$ 4$ and 5 of the Copyright Act, 17 U.S.C. $\$ \$ 4,5$ (1964); and (3) if so, in what class it should be registered.

Regarding video tapes, see Meagher, Copyright Problems Presented by a New Art, 30 N.Y.U. L. REv. 1081 (1955); Needham, Tape Recording, Photocopying, and Fair Use, in 10 ASCAP Copyright LAw SyMrosium 75, 102 (1959).

152 See text accompanying note 48 supra.

153 See id.

154 See Kaplan, supra note 12 , at 367 , for some of these proposals.

155 See text accompanying note 38 sipra. 
applicant for registration without sufficient recourse if his claim happens to be among those rejected.

The chief difficulty with the present system is that in most situations the Register is, for all intents and purposes, the final arbiter of copyrightability. This is so because courts give substantial weight to his issuance of a certificate in assessing copyrightability, ${ }^{156}$ and because of the inherent difficulty in the only recourse against an adverse decision, namely, an action for mandamus. ${ }^{157} \mathrm{He}$ is wellsuited to make that determination in the first instance, because of his day-to-day administration of the copyright statute. But he is also subject to the inherent limitations of an administrator when it comes to deciding difficult questions of copyrightability. Faced with a huge daily volume of applications, ${ }^{158}$ the Register, as an administrator, must minimize the number of exceptional cases. Therefore, having once settled upon a given regulation as defining the outer limits of copyrightability, he is likely to adhere to that position at least until a sufficient number of doubtful cases have arisen to warrant reevaluation. Meanwhile, a number of potentially worthy claims might have been denied registration.

Partial relief from the burdens of the present awkward and unsatisfactory procedure for review is provided in the now-pending Copyright Revision Bill, ${ }^{159}$ which makes a number of basic changes in the system of copyright registration. In the new bill, the Register's duties are made explicit: he is expressly required to register the claim and to issue a certificate of registration

[w] hen, after examination ... [he] determines that, in accordance with the provisions of this title, the material deposited constitutes copyrightable subject matter and that the other legal and formal requirements of this title have been met....160

For the first time he is specifically directed to refuse registration and to notify the applicant in writing of the reasons for his action

[i]n any case in which [he] determines that, in accordance with the provisions of this title, the material deposited does not constitute copyrightable subject matter or that the claim is invalid for any other reason . . . . ${ }^{161}$

156 See note 29 supra and accompanying text; note 31 supra.

157 See discussion of the difficulties attending a mandamus action in text accompanying notes $166-68$ infra.

158 See note 45 supra.

159 H.R. 2512, 90th Cong., 1st Sess. (1967). Failure to agree on some of the new bill's provisions has led to a 4th consecutive one-year extension of the present law. N.Y. Times, May 26, 1968, at 84 , col. 1 .

160 H.R. 2512, 90th Cong., 1st Sess. $\$ 409$ (a) (1967).

161 Id. $\S 409$ (b). 
Reading these two sections together, it is clear that the drafters intended to lay an explicit statutory foundation for the Register's exercise of discretion to reject claims which he finds are not entitled to copyright under the statute. ${ }^{162}$ Section 410 of the bill carries over the requirement of section 13 of the current law that no action for infringement of the copyright in any work shall be instituted until registration of the copyright claim has been made. Section 410 goes on to provide, however, that

[i]n any case .. . where the deposit, application and fee required for registration have been delivered to the Copyright Office in proper form and registration has been refused, the applicant is entitled to institute an action for infringement if notice thereof, with a copy of the complaint, is served on the Register of Copyrights. ${ }^{103}$

As a result of this change, an applicant who has unsuccessfully attempted to obtain registration can nevertheless sue an infringer, subject only to the obligation of notifying the Register. ${ }^{164}$ Thus, the Register's unreviewed refusal to register no longer would create a barrier to bringing an infringement action. ${ }^{165}$

Despite this welcome overruling of the result in Vacheron, the new bill fails to correct two problems in the present law: First, the machinery proposed in section 410 makes no attempt to afford relief to an applicant whose application has been denied registration and whose work is not currently being infringed. Presumably, the rejected applicant would be relegated to a mandamus action against the Register, as under existing law. Mandamus, however, is hardly an adequate substitute for judicial review provided by statute, since it will not be granted to reverse discretionary decisions, at least in the absence of abuse of discretion or arbitrary and capricious action. ${ }^{166}$ This qualification, of course, tends to break down in practice, because courts experience a considerable amount of confusion in attempting to distinguish ministerial from discretionary action, ${ }^{167}$ particularly in matters

162 The existing statute is silent on this point, but the courts have recognized an implied power to reject claims in a number of cases upholding the Register's refusal to issue a certificate. See the discussion at note 32 sipra.

163 H.R. 2512, 90th Cong., 1st Sess. $\$ 410$ (1967).

104 If he so chooses, the Register may then join the action. The Revision Bill provides:

The Register may, at his option, become a party to the action with respect to the issue of registrability of the copyright claim by entering his appearance within sixty days after such service, but his failure to do so shall not deprive the court of jurisdiction to determine that issue.

H.R. 2512, at $\$ 410$.

165 Section 410 was expressly designed to alter the rule of Vacheron \& Constantin-

Le Coultre Watches, Inc. v. Benrus Watch Co., 260 F.2d 637 (2d Cir. 1958). H.R.

Rep. No. 83, 90th Cong., 1st Sess. 125 (1967).

$186 \mathrm{~K}$. Davis, Handbook on Administrative Law $\S 222$, at 764 (1951).

167 Id. at 764-66. 
involving the proper construction of a statute. The availability of mandamus in this situation is rendered still more uncertain by the existence in the Revision Bill of the partial remedy just discussed, for courts might well impute to Congress the intention of making that remedy exclusive. ${ }^{168}$ Thus the new bill would bring about the anomalous result that unsuccessful copyright claimant $\mathrm{A}$ would be afforded a better opportunity to vindicate his interests than unsuccessful copyright claimant $B$, simply because A's copyright had been infringed and B's had not. Yet $B$ has important interests at stake, equally deserving of protection, even though his copyright is not currently being infringed. Registration would make it easier for $B$ to protect his work against unauthorized use because of the procedural advantage gained from establishing presumptive copyrightability before any infringement takes place. If $B$ wishes to dispose of his work, he will find a readier market for it if it has been registered; it might be quite difficult to dispose of an unregistered work, because the assignees or licensees would have little confidence in the validity of the copyright or in B's title. ${ }^{169}$ Indeed, so important is registration, regardless of present infringement, that some claimants have been willing to bring suit to compel registration before any infringement has taken place, despite the obstacles and uncertainties of such actions. ${ }^{170}$

A second defect remaining under the Revision Bill is that, although it provides (substantially as under present law) that a certificate of registration issued within five years of the date of first publication shall constitute prima facie evidence of the validity of the copyright and of the facts stated in the certificate, ${ }^{171}$ no provision is made for any presumption of validity to attach to the facts which would have been stated in a certificate of registration had the Register not declined to issue one.

168 According to Professor Davis, the modern practice regarding the availability of mandamus where another remedy exists is that "[o]rdinarily mandamus may not be resorted to as a mode of review where a statutory method of appeal has been prescribed or to review an appealable decision of record." "Id. at 763-64 (quoting Roche v. Evaporated Milk Ass'n, 319 U.S. 21, 27-28 (1943); see United States ex rel. Girard Trust Co. v. Helvering, 301 U.S. 540 (1937), in which the Court relied on what it termed "the settled rule that the writ of mandamus may not be employed to secure the adjudication of a disputed right for which an ordinary suit affords a remedy equally adequate, and complete." Id. at 544 (citations omitted). It is conceivable that a court could be persuaded by the argument that the partial remedy afforded by the Revision Bill is sufficient to foreclose recourse to mandamus by a rejected applicant, even if that remedy were not yet available because his copyright had not yet been infringed.

169 Kaplan, The Registration of Copyright, in 1 Studies on Copyriget 325, 36869 (1963). 1940).

170 See, e.g., King Features Syndicate, Inc. v. Bouvé, 48 U.S.P.Q. 237 (D.D.C.

171 H.R. 2512, 90th Cong., 1st Sess. $\$ 409$ (c) (1967). This section adds that the evidentiary weight to be accorded the certificate of registration if registration is made later than 5 years from the date of first publication "shall be within the discretion of the court." 
In order to correct the first of these defects, the Revision Bill should make special provision for a civil action against the Register in the United States District Court for the District of Columbia in the event that registration should be finally denied after the informal appeal procedure with the Copyright Office has been exhausted. ${ }^{172}$ Such a provision would afford the unsuccessful claimant a means of trying the validity of his claim without having to wait for an infringement to take place. ${ }^{173}$ All decisions and actions of the Register taken in the course of denying registration should be reviewable de novo ${ }^{174}$ by the district court, allowing both the applicant and the Register to introduce new evidence. Should the claimant succeed in persuading the court that his claim was valid, the court would uphold his copyright and direct the Register to issue a certificate of registration. The court could also direct the Register to amend or withdraw any regulation which conflicted with the court's decision.

Precedent for such a system of de novo judicial review exists under the Patent Act. ${ }^{175}$ That system, somewhat more elaborate, provides first for internal appeal to the Patent Office Board of Appeals by an applicant whose claim has been twice rejected by the Patent Office. ${ }^{178}$ If the applicant is dissatisfied with the Board's decision, he then may elect either to appeal to the Court of Customs and Patent Appeals on the record made in the Patent Office, ${ }^{177}$ or to bring an action de novo against the Commissioner of Patents in the District Court for the District of Columbia. ${ }^{178}$ While the structure created for patent appeals is more complex than is necessary or desirable in the case of copyrights, reflecting the far greater complexity of patent legislation, ${ }^{179}$ there is no reason why copyright law cannot adopt part of the structure without appropriating the whole. There is no need to include the Patent Office internal appeal procedure, with its separate Board of Appeals, but the provision for de novo judicial review does

172 Such a procedure has been suggested by a former Register of Copyrights. See Letter from Clement L. Bouve to the Librarian of Congress, Sept. 17, 1938. A modified version of the Bouvé proposal was suggested in Beran, Refusal to Register$A$ Roadblock to Copyright Ozeners, 10 BuLl. Copyright Soc'x 147, 159-64 (1963). This writer's recommendation represents a further modification of Beran's proposal.

173 The machinery provided in the Revision Bill to expedite the suit of a claimant whose copyright is presently being infringed would be retained as an alternative remedy under this proposal.

174 Such an appeal should not be confined to the record made in the Copyright Office, since a determination of copyrightability should be made on the basis of all available evidence. This is especially true considering the lack of any formalized internal appeal system in the Office, and hence of any adequate record-making procedures.

17535 U.S.C. $\S \S 1-293$ (1964).

$176 I d . \S 134$.

$177 I d . \$ 141$.

178 Id. $\$ 145$. The two remedies are mutually exclusive.

179 Patent applications, unlike copyright registrations, entail a search of the prior art as well as an assessment of novelty and inventiveness. For the conditions under which patents are granted, see id. $\$ \$ 100-04$. 
furnish a desirable model. The court would not be confined by the narrow strictures on a remedy in the nature of mandamus, ${ }^{180}$ but would be free to weigh all the relevant arguments of law and policy advanced by the parties in order to decide whether the Register's refusal was proper in the light of all the circumstances.

To remedy the second failing of the Revision Bill, that is, to facilitate a challenge to the Register's decision not to issue a certificate, the new Copyright Act should provide that if the Register's refusal is based on the ground of uncopyrightability of the subject matter (the claimant having complied with all the formal requirements of the law as proposed in the Bill-that is, if the deposit, application, and fee required for registration have all been delivered to the Copyright Office in proper form ${ }^{181}$ ), then the Register should be required to issue, upon request, a special document to be called a Certificate of Administrative Compliance. ${ }^{182}$ This document would state (1) that the Register had examined the application and found it to have satisfied all the administrative requirements for copyright registration; and (2) that a certificate of registration had been denied, setting forth the reasons for the denial. The Certificate of Administrative Compliance would be deemed prima facie evidence of the same facts as the present certificate of registration; ${ }^{183}$ unlike the certificate of registration, however, it would create no presumption regarding copyrightability.

The experience of nearly sixty years under the 1909 Act has shown that the discretion of the Register to refuse registration to claims he considers unwarranted or ill-founded serves a useful function. Yet the extremely wide range of his discretion calls for an effective counterweight in the form of readily available recourse to remedial machinery, in order to prevent disadvantage to claimants in case the Register's denial of registration is improper. Presently available methods of review are, however, clumsy and unwieldy.

Under the new bill, correcting a misjudgment of the Register would be made easy for one whose copyright has been infringed. Rejected applicants whose claimed copyright is not presently being infringed, however, should have a similarly available remedy so that they will not unjustly be deprived of the advantages of registration apart from the right to sue. The proposed additions to the Revision

180 See text accompanying notes 166-68 supra.

181 These requirements are covered in $\$ \$ 406,408$, and 708 respectively, of the Revision Bill, H.R. 2512, 90th Cong., 1st Sess. (1967).

182 The issuance of a Certificate of Administrative Compliance under slightly different conditions is proposed in Beran, supra note 172, at 162-63.

183 See note 30 supra. 
Bill would go further toward alleviating the present imbalance between the power of the Register and the rights of rejected applicants, by making the remedies for all such applicants essentially identical, regardless of whether infringement had taken place. Yet these proposals do not significantly limit the theoretical power of the Register; on the contrary, they would preserve his administrative role, while relieving him of the burden of making what amount to rulings of law. These changes should be incorporated into the new law in the best interests of an equitable system. 